\title{
Experiments with the long-term rumen simulation technique (Rusitec); response to supplementation of basal rations
}

\author{
BY J. W. CZERKAWSKI AND GRACE BRECKENRIDGE \\ The Hannah Research Institute, Ayr, Scotland KA6 ${ }_{5} H L$
}

(Received 2 January 1979 - Accepted 26 February 1979)

\begin{abstract}
I. It is shown that a basal roughage diet can be successfully supplemented with glucose, as long as nitrogen is not limiting. Lack of $\mathrm{N}$ depresses the digestibility of the basal ration, results in incomplete fermentation and the increased recoveries of $\mathrm{N}$ are consistent with fixation of atmospheric $\mathrm{N}_{2}$.

2. Using a complex, but soluble supplement (whey powder) it is shown that reproducible incremental measurements can be made and that the supplement used gives increases in production of characteristic end-products only (carbon dioxide, methane, acetic and butyric acids).

3. The location of the solid dietary components within the reaction vessel is not important and it is possible to measure changes in a particular component in the presence of others. It is shown that there is sequestration of bacteria and protozoa on the solid digesta.
\end{abstract}

The design, construction and operation of an apparatus for simulating rumen fermentation under controlled conditions (Rumen Simulation Technique; Rusitec) have been described by Czerkawski \& Breckenridge (1977). The most important features in this technique are the simplicity of construction and operation, the use of ordinary ruminant food, the ability to maintain a steady fermentation pattern that is very similar to the pattern observed in the rumen of the donor animals and to have up to four replicates.

To illustrate the potential of the apparatus, three types of experiments were reported (the effect of dilution rates, levels of feeding and composition of ration upon fermentation) (Czerkawski \& Breckenridge, 1977). It was found that the dilution rate did not have a marked effect on fermentation and output of products of fermentation, that the amounts of products increased with the level of feeding and that the fermentation pattern depended on the composition of the ration. Moreover, using wholly roughage or $800 \mathrm{~g}$ concentrate $/ \mathrm{kg}$ ration and inocula from sheep on the same diet, it was possible, by interchanging the diets in the experimental vessels, to interchange the characteristic fermentation patterns. This showed that the type of fermentation in Rusitec and possibly in the rumen may be largely determined by the diet.

In most experiments the roughage and concentrate components of the rations were mixed and although the digestibility of the ration was considerably greater with the concentrate diet than with roughage only, it was impossible to tell whether this was due to increased digestibility of both components or a big increase in digestibility of one component, possibly compensating for a decrease in the digestibility of the other. This aspect of fermentation of the concentrate supplement could be investigated in Rusitec by the simple expedient of placing the concentrate and roughage components of the ration in separate nylon gauze bags. This type of experiment would also give an opportunity to study in more detail the distribution of microbial matter in the liquid and solid digesta and the contribution of such a distribution to the simulation of rumen fermentation in our apparatus.

The function of supplements in fermentation was investigated in several long-term experiments. Some experiments were done specifically to investigate this aspect of rumen fermentation, others were part of larger experiments that will not be reported here in full. In the first experiment the supplement was glucose infused continuously and the objective was to measure the incremental output of end-products of fermentation and microbial 
synthesis to see if the supplement would have any effect on the digestion of the basal roughage diet and to define the nitrogen requirements in these fermentations. In the second and third experiments, the basal ration contained a proportion of concentrate and the supplement was whey powder. This material is used in several commercial feeds and it was introduced into each reaction vessel with the basal ration. The last experiment was designed primarily to see what happens to the concentrate when incubated in the presence of roughage and if the fact that the two components of the diet are incubated as a mixture or in separate nylon-gauze bags would have any effect on fermentation. Some of the experiments described here have been reported briefly (Czerkawski \& Breckenridge, $1978 a, b)$.

\section{EXPERIMENTAL}

\section{Methods and materials}

The apparatus used was Rusitec described by Czerkawski \& Breckenridge (1977), or a modification of this technique, in which the reaction vessels were somewhat shorter, but with larger cross-sectional area, resulting in an increased reaction volume ( $\mathrm{I} \cdot 41$ instead of $I \cdot O l$ in the original apparatus). The inocula for starting Rusitec experiments were obtained from sheep provided with rumen cannulas and given the same basal diets as used in the artificial rumen.

Most of the analytical procedures used were as described by Czerkawski \& Breckenridge (1977). The gas composition was determined as described by Czerkawski \& Clapperton (I968) and the concentrations of volatile fatty acids (VFA) were determined by the method of Cottyn \& Boucque (1968) using pivalic acid as internal standard (Czerkawski, 1976a). The analyses of nitrogenous compounds included: $\alpha$-amino group (Spies, 1952), diaminopimelic acid (DAP) (Czerkawski, 1974) content after hydrolysis, total $\mathrm{N}$ and ammonia-N (Czerkawski, 1974). The microbial output in the effluent was determined as particulate dry matter (DM) after centrifuging the suspension at $15000 \mathrm{~g}$ for $30 \mathrm{~min}$ and washing on the centrifuge, and the microbial output in the undigested residue was as DAP and aminoethylphosphonic acid (AEP) as described by Czerkawski (1974), after removal of the microbial matter from the solid by sonication in dilute sodium hydroxide solution (Czerkawski, I976b).

Microbial counts in the effluent and on some occasions in samples of the reaction mixture were made as described by Czerkawski et al. (1975). In some experiments the concentration of lactic acid was determined by the method of Pryce (1969).

The DM content of food and undigested residue was determined by drying at $105^{\circ}$ and weighing; the cellulose, neutral- and acid-detergent fibre were determined by the methods of Crampton \& Maynard (1938), Van Soest \& Wine (1967) and Van Soest (1963) respectively.

\section{Experimental procedures}

Expt $\mathrm{I}$. Nominal volume of reaction vessel $\mathrm{I} \cdot \mathrm{o} l$. The basal ration in this experiment consisted of $8 \mathrm{~g}$ chopped hay $(6.99 \mathrm{~g} \mathrm{DM})$. Throughout the duration of the experiment $(22 \mathrm{~d})$, the basal ration was unsupplemented in vessel no. I, supplemented with glucose in vessel no. 2 , ammonium chloride in vessel no. 3 and both glucose and $\mathrm{NH}_{4} \mathrm{Cl}$ in vessel no. 4 , by infusion of these substances as solution in the artificial saliva. When glucose was infused the $\mathrm{pH}$ of artificial saliva was increased from 8.0 to 9.5 to give mean $\mathrm{pH}$ of reaction mixture close to 7.0. During days $12-22$ the mean inputs of glucose in vessel nos. 2 and 4 were $2.9 \mathrm{I}$ and $2.92 \mathrm{~g} / \mathrm{d}$ and the mean inputs of $\mathrm{NH}_{3}-\mathrm{N}$ in vessel nos. 3 and 4 were 93.5 and $84 . \mathrm{Img} / \mathrm{d}$ respectively. The samples of gas, effluent liquid and undigested residues were analysed daily throughout the experiment. 
Expt 2. Nominal volume of reaction vessel $\mathrm{I} \cdot 4 l$. These experiments were parts of much larger experiments using four vessels, in which the basal rations were also supplemented with tallow and a tallow and a whey-compound (reported briefly by Czerkawski \& Breckenridge, $1978 a$ ). Results for 2 vessels are given here.

In Expt $2 a$ the basal ration consisted of a mixture of chopped hay (I6.II g DM) and bruised barley ( $\cdot 72 \mathrm{~g} \mathrm{DM})$ and this was supplemented with $5 \mathrm{~g}$ whey powder $(4 \cdot 70 \mathrm{~g} \mathrm{DM})$. In Expt $2 b$ the basal ration was chopped hay, bruised barley and soya-bean meal (17.06, $\mathrm{I} \cdot 72$ and $0.86 \mathrm{~g}$ DM respectively), and this was supplemented with $\mathrm{I} \cdot 5 \mathrm{~g}$ whey powder. In Expt $2 a$ basal rations were used for the first io $\mathrm{d}$ of the experiment and they were supplemented with whey during the remainder (days I $1-23$ ). In Expt $2 b$, the basal rations were supplemented with whey during days 9-1 8 of the 24-d experiment, days 5-8 and days 2-24 serving as the initial and final controls. Most of the analyses were done on the bulked samples for control and treatment periods.

The production of end-products of fermentation, the microbial outputs and the digestibility of food were measured either daily or in bulked samples.

Expt 3. Nominal volume of reaction vessels $\mathrm{I} \cdot 4 l$. Two vessels were used in this experiment. In one vessel the ration was chopped hay ( $8.84 \mathrm{~g} \mathrm{DM})$ and bruised barley (I3.73 $\mathrm{g} \mathrm{DM}$ ) introduced into the vessel as a mixture in a nylon-gauze bag, while in the other vessel the same amounts of hay and barley were kept in separate bags. Since the $\mathrm{N}$ content of hay and barley was low, these two components were supplemented with soya-bean meal (0.88 $\mathrm{g} \mathrm{DM}$ ). This was placed into the vessels just before the vessels were closed and flushed with gas $\left(50 \mathrm{ml}\right.$ carbon dioxide $/ 1 \mathrm{~N}_{2}$ ). On day II of the experiment the treatments in the two vessels were interchanged and the experiment was continued until the outputs were constant for at least $4 \mathrm{~d}$.

As described previously, the undigested residues of a mixture of hay and barley were washed twice with $40 \mathrm{ml}$ artificial saliva and the washings were put back into the vessels. However, when the two dietary components were incubated in separate bags, the residues of hay were washed twice with $30 \mathrm{ml}$ and the residues of barley were washed twice with ro $\mathrm{ml}$ artificial saliva. Small samples of washings were kept for microbial counts. Because the major constituent of the diet (barley) was digested quite extensively, the perfusion of solid was improved by placing a block of nylon (quadrant cross-section) in each vessel.

Samples of gas and the VFA in the effluent were analysed every day during the bulking periods (days 6-10 and $14-18$ ) and every second day during the rest of the experimental period. Bulked samples of effluent were used to determine the output of VFA, lactic acid and microbial matter. The undigested residues were also bulked during days 6-10 and 14-I 8 and used for the determination of DM, cellulose, acid- and neutral-detergent fibre and the content of microbial matter.

\section{RESULTS}

\section{Expt I. Supplementation of hay with glucose and $\mathrm{NH}_{4} \mathrm{Cl}$}

The basal ration of hay used in this experiment resulted in a relatively long period of adaptation (approximately Io d) compared with 4-6 d for more balanced diets. The digestibility of hay DM declined to a minimum 6-7 d after the start of the experiment in the control vessel and during supplementation with $\mathrm{NH}_{4} \mathrm{Cl}$ (approximately 0.25 ), and then increased to a higher steady value of approximately 0.55 after day IO (Fig. I). Supplementation of the basal ration of hay with glucose resulted in a steady decline of digestibility of hay to approximately 0.35 , while the supplementation of hay with both glucose and $\mathrm{NH}_{4} \mathrm{Cl}$ resulted in a gradual increase in digestibility of hay during the first $10 \mathrm{~d}$ of the experiment and a steady value henceforth. These changes in digestibility were consistent with changes in the production of VFA and gases. 


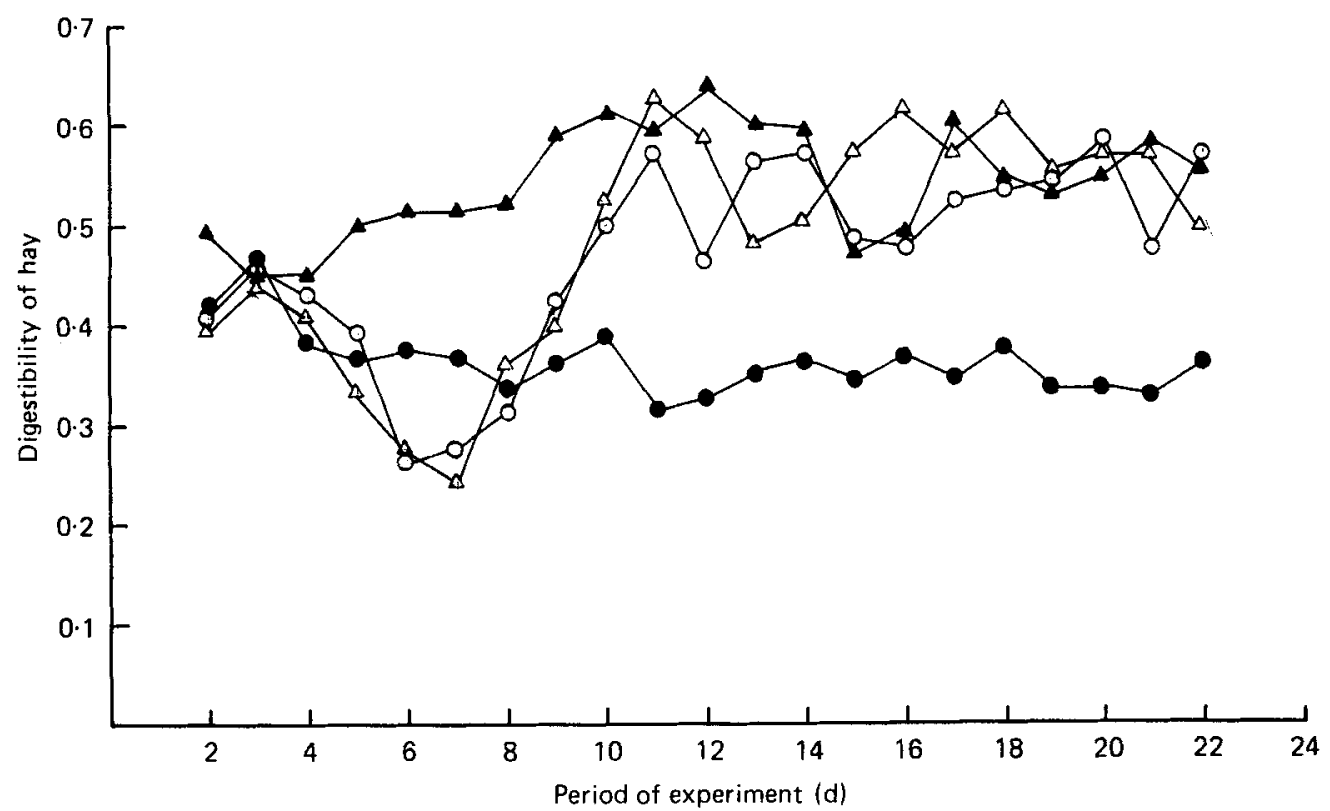

Fig. I. Changes in the digestibility of hay during incubation by the Rumen Simulation Technique (Rusitec) and the effect of supplementation with glucose (-), ammonium chloride $(\triangle-\triangle)$ or both $(\Delta-\Delta)$. $(\mathrm{O}-\mathrm{O})$ control.

The outputs of gases, VFA and microbial DM are summarized in Table $I$ as means for days 12-22. The molar proportions of VFA were as expected for a high-roughage ration (high proportion of acetate) in all but one vessel; when hay was supplemented with glucose only, there was more butyric than propionic acid and there was some accumulation of isovaleric acid. The output of microbial DM increased slightly during infusion of glucose and increased considerably when both glucose and $\mathrm{N}$ were supplementing the basal ration. The increase was mainly in the liquid phase of the digesta.

The results summarized in Table 2 show the depression in digestibility of hay DM during acute shortage of $\mathrm{N}$ (see the concentration of $\mathrm{NH}_{3}$ ), and similar changes in the digestion of hemicellulose (neutral-detergent fibre minus acid-detergent fibre). When the basal rations were supplemented with glucose, there was an increase in insoluble carbohydrate (microbial storage polysaccharide; $420 \mathrm{~g} / \mathrm{kg}$ microbial DM, when $\mathrm{N}$ was limiting) and a large increase in protein when both glucose and $\mathrm{N}$ were added. The measurements of the concentration of substances in solution showed that most of the infused glucose was digested and that there was sufficient $\mathrm{N}$ in hay for its relatively poor contribution to fermentation. The large increase in microbial synthesis associated with supplementation of hay with both glucose and $\mathrm{N}$ resulted in considerable uptake of $\mathrm{NH}_{3}$, but since there was finite outflow of $\mathrm{NH}_{3}$, it must be concluded that $\mathrm{N}$ was not limiting under these conditions.

The recovery of $\mathrm{N}$ when $\mathrm{N}$ was limiting was $105 \%$ (glucose infusion), while the mean recovery when it was not limiting in the other three vessels was $97 \%$. This suggests that there may be fixation of atmospheric $\mathrm{N}_{2}$ when its supply in food is limited. Using the values in Tables $I$ and 2 it was possible to calculate the incremental increases due to addition of glucose without and with addition of $\mathrm{N}$. The amounts of glucose digested were 95 and $93 \%$ in vessels nos. 2 and 4 respectively. The increment in the products of fermentation accounted for 1.37 and $2.02 \mathrm{~g}$ glucose when $\mathrm{N}$ was limiting and when $\mathrm{N}$ was in excess 
Table I. Expt I. Production of gases and volatile fatty acids (VFA) and synthesis of microbial matter during fermentation of hay by the Rumen Simulation Technique (Rusitec) and the effect of supplementation with glucose, ammonium chloride and both compounds

(The results are means in three bulked samples for days 12-22. The pH value was maintained between 7.1 and 7.2 in all vessels; the output of lactic acid was determined; it ranged from 0.02 to $0.05 \mathrm{mmol} / \mathrm{d}$. The mean dilution rate was $0.66 / \mathrm{d}$ )

\begin{tabular}{|c|c|c|c|c|c|c|c|c|}
\hline & \multicolumn{2}{|c|}{ Control } & \multicolumn{2}{|c|}{ Glucose } & \multicolumn{2}{|c|}{$\mathrm{NH}_{\mathbf{c}} \mathrm{Cl}$} & \multicolumn{2}{|c|}{$\begin{array}{c}\text { Glucose and } \\
\mathrm{NH}_{\mathbf{6}} \mathrm{Cl}\end{array}$} \\
\hline & Mean & SE & Mean & SE & Mean & SE & Mean & SE \\
\hline $\begin{array}{l}\text { Gases }(\mathrm{mmol} / \mathrm{d}) \\
\text { Carbon dioxide } \\
\text { Methane }\end{array}$ & $\begin{array}{r}14.9 \\
5.8\end{array}$ & $\begin{array}{l}0.9 \\
0.2\end{array}$ & $\begin{array}{l}22 \cdot 4 \\
\text { II } 4\end{array}$ & $\begin{array}{l}0.6 \\
0.4\end{array}$ & $\begin{array}{r}15.8 \\
5.6\end{array}$ & $\begin{array}{l}I \cdot I \\
0 \cdot 3\end{array}$ & $\begin{array}{l}32 \cdot 1 \\
14.4\end{array}$ & $\begin{array}{l}2.0 \\
0.5\end{array}$ \\
\hline $\begin{array}{l}\text { VFA (mmol/d) } \\
\text { Acetic } \\
\text { Propionic } \\
\text { Butyric } \\
\text { Isovaleric } \\
\text { Valeric }\end{array}$ & $\begin{array}{r}17.8 \\
3.6 \\
1.5 \\
0.3 \\
0.0\end{array}$ & $\begin{array}{l}0.3 \\
0.1 \\
0.1 \\
0.1 \\
-\end{array}$ & $\begin{array}{r}25.3 \\
2.5 \\
2.6 \\
2.3 \\
0.1\end{array}$ & $\begin{array}{l}0.5 \\
0.1 \\
0.4 \\
0.2 \\
-\end{array}$ & $\begin{array}{r}18.5 \\
3.7 \\
1.5 \\
0.2 \\
0.1\end{array}$ & $\begin{array}{l}0.4 \\
0.1 \\
0.1 \\
0.1 \\
-\end{array}$ & $\begin{array}{r}33.0 \\
3.8 \\
3.3 \\
0.4 \\
0.6\end{array}$ & $\begin{array}{l}0.5 \\
0.1 \\
0.1 \\
0.1 \\
-\end{array}$ \\
\hline $\begin{array}{l}\text { Microbial matter (g/d) } \\
\text { Effluent particulate DM } \\
\text { In undigested residue* }\end{array}$ & $\begin{array}{l}0.18 \\
0.44\end{array}$ & $\begin{array}{l}0.02 \\
0.03\end{array}$ & $\begin{array}{l}0.27 \\
0.51\end{array}$ & $\begin{array}{r}0.01 \\
\pm 0.02\end{array}$ & $\begin{array}{l}0.22 \\
0.44\end{array}$ & $\begin{array}{l}0.02 \\
0.08\end{array}$ & $\begin{array}{l}0.71 \\
0.41\end{array}$ & $\begin{array}{l}0.05 \\
0.01\end{array}$ \\
\hline Total & 0.62 & - & 0.78 & 一 & 0.66 & - & I'II & - \\
\hline
\end{tabular}

DM, dry matter.

- Estimated from the diaminopimelic acid and aminoethyl phosphonic acid content.

respectively and the increments in the output of microbial matter accounted for 0.19 and $0.52 \mathrm{~g}$ glucose under the same conditions, giving a mean recovery of approximately $90 \%$. The results showed also that, of the glucose accounted for, only $12 \%$ was converted to microbial matter when $\mathrm{N}$ was limiting and that over $20 \%$ was converted to microbial matter when there was sufficient $\mathrm{N}$ supply.

\section{Expt 2. Supplementation with whey powder}

Some of the results of Expts $2 a$ and $2 b$ are summarized in Table 3 . The mean dilution rate in Expt $2 a(0.64 / \mathrm{d})$ was a little lower than the mean dilution rate in Expt $2 b(0.69 / \mathrm{d})$. The basal rations were very similar in both experiments, but with larger reaction vessels used in these experiments ( $\mathrm{I} \cdot 4 \mathrm{O}$ l) it was possible to increase the amount of roughage (hay) and some additional $\mathrm{N}$ was supplied in the form of soya-bean meal. It was possible to keep the $\mathrm{pH}$ within limits of 6.85 and 7.05 within all vessels.

The increase in production of methane in Expt $2 a$ was relatively small and there was some accumulation of hydrogen gas, while the methane increment in Expt $2 b$ was quite large. Possibly the extent of supplementation in Expt $2 a$ was too large. In both experiments the fermentation of whey powder resulted in relatively large production of acetic and butyric acids. In Expt $2 a$ there was an increase in production of odd-carbon-number VFA, whereas in Expt $2 b$ the addition of whey powder actually resulted in a decreased production of these compounds. Thus, the high incremental production of methane appeared to be compensated by a lower production of propionic and $C_{b}$ acids; both processes requiring hydrogen.

Even though the whey powder is a soluble substrate, the supplementation of the basal diet with whey gave little or no increase in the output of bacterial DM in the effluent. There 
Table 2. Expt I. Inputs and outputs of carbohydrates and nitrogen compounds during fermentation of hay by the Rumen Simulation Technique (Rusitec) and the effect of supplementation with glucose, ammonium chloride and both compounds

(The results are means of daily determinations during days 12-22 or means of three determinations on bulked samples (days $\mathrm{I2}-15,16-19,20-22)$. The hay ration $(8 \mathrm{~g} / \mathrm{d}$ ) provided 6.99 $\mathrm{g} \mathrm{DM}, 295 \mathrm{~g}$ ADF, $5.08 \mathrm{~g} \mathrm{NDF}$ and $91.5 \mathrm{mg} \mathrm{N}$ )

\begin{tabular}{|c|c|c|c|c|c|c|c|c|}
\hline & \multicolumn{2}{|c|}{ Control } & \multicolumn{2}{|c|}{ Glucose } & \multicolumn{2}{|c|}{$\mathrm{NH}_{4} \mathrm{Cl}$} & \multicolumn{2}{|c|}{$\begin{array}{l}\text { Glucose } \\
+\mathrm{NH}_{4} \mathrm{Cl}\end{array}$} \\
\hline & Mean & SE & Mean & SE & Mean & SE & Mean & SE \\
\hline \multicolumn{9}{|l|}{$\begin{array}{l}\text { Input of } \\
\text { supplements }\end{array}$} \\
\hline Glucose $(g / d)$ & 0.0 & - & $2 \cdot 91$ & - & 0.0 & - & 2.92 & - \\
\hline $\mathrm{NH}_{4} \mathrm{Cl}(\mathrm{N} \mathrm{mg} / \mathrm{d})$ & 0.0 & - & 0.0 & - & $93 \cdot 5$ & - & $84 \cdot I$ & - \\
\hline \multicolumn{9}{|l|}{$\begin{array}{l}\text { Undigested } \\
\text { residue }\end{array}$} \\
\hline $\mathrm{DM}(\mathrm{g} / \mathrm{d})$ & $3 \cdot 28$ & 0.10 & 4.53 & 0.03 & 3.07 & 0.10 & $3 \cdot 02$ & 0.10 \\
\hline $\begin{array}{l}\text { Hemicellulose } \\
\text { (NDF-ADF) } \\
\text { (g/d) }\end{array}$ & 0.92 & 0.01 & $I \cdot 33$ & 0.03 & 0.86 & 0.10 & 0.86 & 0.05 \\
\hline$N(\mathrm{mg} / \mathrm{d})$ & $39 \cdot 7$ & $1 \cdot 5$ & $47 \cdot 3$ & $3 \cdot 2$ & 40.0 & $2 \cdot 3$ & $40 \cdot 2$ & 47 \\
\hline \multicolumn{9}{|l|}{$\begin{array}{l}\text { Effluent } \\
\text { Particulate } \\
\text { matter }(\mathrm{mg} / \mathrm{d})\end{array}$} \\
\hline $\begin{array}{l}\text { Carbohydrate } \\
\text { Protein* }\end{array}$ & $\begin{array}{l}32 \cdot 5 \\
64 \cdot 0\end{array}$ & $\begin{array}{l}5 \cdot 3 \\
6 \cdot 6\end{array}$ & $\begin{array}{r}\text { I I6.4 } \\
88 \cdot 9\end{array}$ & $\begin{array}{l}2 \cdot 8 \\
1 \cdot 5\end{array}$ & $\begin{array}{l}42 \cdot 2 \\
85 \cdot 0\end{array}$ & $\begin{array}{l}3.4 \\
0.9\end{array}$ & $\begin{array}{l}144^{\cdot 2} \\
329^{\circ} I\end{array}$ & $\begin{array}{r}14.1 \\
6.5\end{array}$ \\
\hline \multicolumn{9}{|l|}{ In solution $(\mathrm{mg} / \mathrm{d})$} \\
\hline $\begin{array}{l}\text { Carbohydrate } \\
\text { Protein }\end{array}$ & $\begin{array}{r}32 \cdot 4 \\
\mathrm{I} \cdot 0\end{array}$ & $\begin{array}{l}1.0 \\
0.5\end{array}$ & $\begin{array}{r}30.3 \\
1 \cdot 0\end{array}$ & $\begin{array}{l}1.5 \\
0.7\end{array}$ & $\begin{array}{r}32.1 \\
1.9\end{array}$ & $\begin{array}{l}1.8 \\
0.6\end{array}$ & $\begin{array}{r}48.8 \\
6.9\end{array}$ & $\begin{array}{l}2.2 \\
0.3\end{array}$ \\
\hline $\mathrm{NH}_{3} \mathrm{~N}$ & $9 \cdot 2$ & $1 \cdot 6$ & trace & - & $84 \cdot 4$ & $1 \cdot 7$ & $17 \cdot 4$ & $3 \cdot 3$ \\
\hline $\begin{array}{l}\text { Total } N \text { in effluent } \\
(\mathrm{mg} / \mathrm{d})\end{array}$ & $45 \cdot 7$ & $I \cdot O$ & $48 \cdot 3$ & $2 \cdot 0$ & $148 \cdot 5$ & $3 \cdot 5$ & $136 \cdot 7$ & $4 \cdot 1$ \\
\hline
\end{tabular}

ADF, acid-detergent fibre; NDF, neutral-detergent fibre; DM, dry matter.

* Protein determined as $\alpha$-amino content (mmol $\times$ I02).

was a significant increase in the output of bacterial DM in the undigested residue in both experiments. The whey powder used contained $(\mathrm{g} / \mathrm{g} \mathrm{DM})$ : lactose 0.69 , protein 0.13 , lipid 0.04 and ash 0.13 and had it not been digested, such supplementation would have caused a daily output of approximately 2070 and $390 \mathrm{mg}$ carbohydrate and protein respectively in Expt $2 a$ and approximately 670 and $126 \mathrm{mg}$ carbohydrate and protein in Expt $2 b$. The incremental increases in the output of soluble carbohydrate and protein were small or negligible, showing that most of the added whey was digested. If it is assumed that the increments of gases and VFA listed in Table 3 are due to lactose, it is possible to make stoichiometric calculations and to show that the products correspond to 8 and $3 \mathrm{~mol}$ lactose in Expts $2 a$ and $2 b$ respectively and that this corresponds to 3.96 and $\mathrm{I} \cdot 49 \mathrm{~g}$ whey DM respectively, close to the amounts digested.

\section{Expt 3. Incubation of hay and barley}

The results are summarized in Tables 4,5 and 6 . Incubation of hay and barley in separate bags resulted in a small increase in production of acetic and propionic acids ( 4 and $7 \%$ respectively) and a decrease in production of butyric acid $(5 \%)$ compared with the incubation of mixtures. There was also an increase in the outputs of methane ( $8 \%$ ) and bacterial DM ( $7 \%$ ) (see Table 4$)$. The total amount of DM digested increased by approximately 
Table 3. Expt 2. Output of gases, volatile fatty acids (VFA) and bacterial DM during incubation of hay and barley and the effect of whey powder supplement $(5.0 \mathrm{~g} / \mathrm{d}$ in Expt $2 \mathrm{a}$ and $\mathrm{I} \cdot 5 \mathrm{~g} / \mathrm{d}$ in Expt $2 \mathrm{~b})$; the inputs of $\mathrm{DM}$, the extent of digestion and the output of soluble nutrients are also given

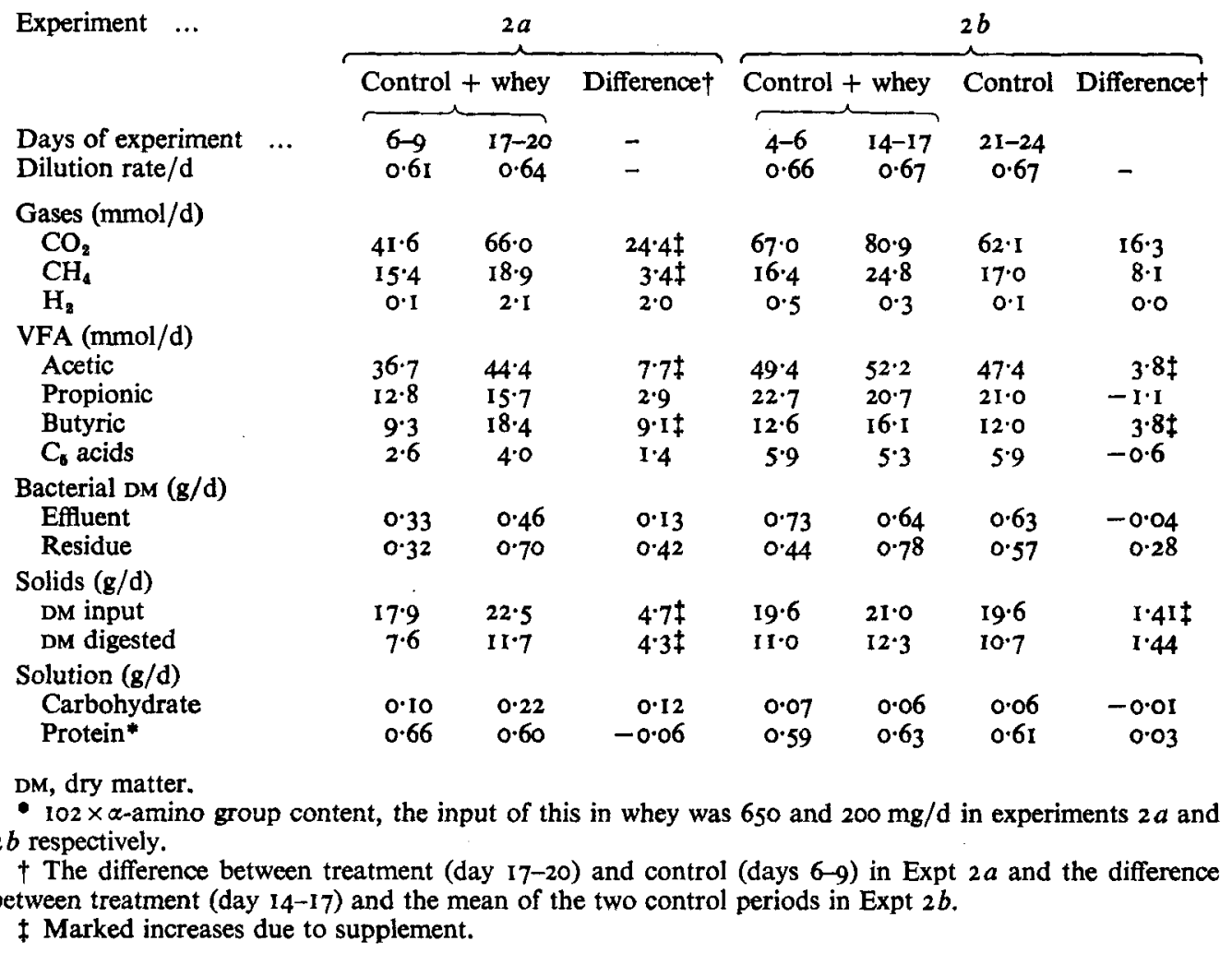

$3 \%$ when hay and barley were incubated in separated bags but there was no change in the amount of cellulose digested (Table 5 ). The digestibility of barley DM was considerably greater $(0.85)$ than the digestibility of hay DM $(0.47)$. Since the output of carbohydrate in the effluent liquid was $0.3 \mathrm{~g} / \mathrm{d}$ and a large proportion of that was microbial (approximately $0.2 \mathrm{~g} / \mathrm{d}$ ) and since the digestibility of cellulose in barley was lower than that of hay, it must be concluded that the non-structural carbohydrate of barley was digested completely.

The concentrations of bacteria and protozoa in the effluent fluid, in the undigested residues and in the washings of the residues are shown in Table 6 . The microbial counts are not accurate enough to show any change due to incubation of the food components together or in separate bags. However, it can be seen that the concentration of protozoa in the washings was much greater than the concentration in the effluent while the concentration of bacteria in the washings was only slightly greater than in the effluent. The estimated concentrations of both bacteria and protozoa in the solid rumen contents appear to be considerably greater than in the liquid contents.

Using the values in Tables 4,5 and 6 it is possible to show that of the total bacteria in the reaction vessel, approximately $31 \%$ are in the solid phase (residue + washings) and that the solid phase may contain $56 \%$ of total protozoa in the reaction vessel. Approximately $75 \%$ of total bacteria in the reaction vessel are removed every day ( $52 \%$ in the effluent) 
Table 4. Output of products during fermentation of hay and barley by the Rumen Simulation Technique (Rusitec) in a simple change-over experiment

(The results are means for days 6-10 and 14-I 8 in vessels nos. 1 and 2 respectively (components in the same bags) and for days $14-18$ and 6-10 in vessels nos. I and 2 respectively (components in separate bags). Values in parentheses are amounts of total particulate DM)

\begin{tabular}{|c|c|c|}
\hline Dilution rate/d & $\begin{array}{l}\text { Components in } \\
\text { the same bag } \\
0.43\end{array}$ & $\begin{array}{c}\text { Components in } \\
\text { separate bags } \\
0.48\end{array}$ \\
\hline Methane (mmol/d) & $27^{\circ} 0$ & $29 \cdot 4$ \\
\hline \multicolumn{3}{|l|}{$\begin{array}{l}\text { Volatile fatty acids* } \\
\text { (mmol/d) }\end{array}$} \\
\hline Acetic & $46 \cdot 2$ & $48 \cdot I$ \\
\hline Propionic & 159 & $17 \cdot 1$ \\
\hline Butyric & $27 \cdot 5$ & $26 \cdot 2$ \\
\hline Isovaleric & $2 \cdot 9$ & $3 \cdot 3$ \\
\hline Valeric & 7.9 & $8 \cdot 0$ \\
\hline $\mathrm{C}_{\mathrm{B}}$ & 44 & $4 \cdot 2$ \\
\hline \multicolumn{3}{|l|}{ Bacterial DM $(\mathrm{g} / \mathrm{d}) \dagger$} \\
\hline In effluent & $0.92(\mathrm{I} .45)$ & I. or $(I \cdot 44)$ \\
\hline In residue & 0.43 & 0.43 \\
\hline
\end{tabular}

DM, dry matter.

* The production of lactate was low when hay and barley were incubated together and separately (0.09 and 0.1 I $\mathrm{mmol} / \mathrm{d}$ respectively).

$\dagger$ When hay and barley were incubated in separated bags, $75 \%$ diaminopimelic acid in undigested material was in the hay residue and $25 \%$ was in the barley residue.

Table 5. Digestion of DM, cellulose and hemicellulose (neutral detergent fibre-acid detergent fibre) during incubation of hay and barley by the Rumen Simulation Technique (Rusitec) as mixtures in single nylon-gauze bags $(A)$ or in separate bags $(B)$

(The results are means of duplicate analyses of bulked samples for days 6-1o and days $14-18(\mathrm{~g} / \mathrm{d})$ )

\begin{tabular}{|c|c|c|c|c|c|}
\hline & \multirow[t]{2}{*}{ Inputs* } & \multicolumn{2}{|c|}{ Outputs } & \multicolumn{2}{|c|}{ Digested } \\
\hline & & A & B & A & B \\
\hline $\begin{array}{l}\text { DM } \\
\text { Hay } \\
\text { Barley }\end{array}$ & $\left.\begin{array}{r}8 \cdot 48 \\
13 \cdot 73\end{array}\right\} 22 \cdot 21$ & $6 \cdot 86$ & $\left.\begin{array}{l}4 \cdot 43 \\
1 \cdot 99\end{array}\right\} 6 \cdot 43$ & $15 \cdot 35$ & $\left.\begin{array}{r}4 \cdot 05 \\
I I \cdot 74\end{array}\right\}$ I $5 \cdot 79$ \\
\hline $\begin{array}{c}\text { Cellulose } \\
\text { Hay } \\
\text { Barley }\end{array}$ & $\left.\begin{array}{l}3.70 \\
1.05\end{array}\right\} 4.75$ & $2 \cdot 93$ & $\left.\begin{array}{l}2 \cdot 16 \\
0.76\end{array}\right\} 2.92$ & $I \cdot 82$ & $\left.\begin{array}{l}1.54 \\
0.29\end{array}\right\} \quad I .83$ \\
\hline $\begin{array}{c}\text { Hemicellu } \\
\text { Hay } \\
\text { Barley }\end{array}$ & $\left.\begin{array}{l}2.36 \\
I .45\end{array}\right\} 3.8 I$ & $2 \cdot 48$ & $\left.\begin{array}{l}1.48 \\
0.52\end{array}\right\} 2.00$ & $I \cdot 33$ & $\left.\begin{array}{l}0.88 \\
0.93\end{array}\right\} \quad 1.81$ \\
\hline
\end{tabular}

* The daily inputs did not include the soya-bean meal $(0.88,0.13$ and $0.01 \mathrm{~g} \mathrm{DM}$, cellulose and hemicellulose respectively).

and approximately $68 \%$ of protozoa are removed ( $33 \%$ in the effluent). Clearly, the total proportions of micro-organisms removed every day were similar to the nominal dilution rate $(0 \cdot 72 / \mathrm{d})$ but the proportions removed in the liquid were considerably smaller than the dilution rate.

This experiment was continued for a further $8 \mathrm{~d}$, with hay and barley placed in the same bags, but with different dilution rates; $0.55 / \mathrm{d}$ in vessel no. I and $\mathrm{I} \cdot \mathrm{I} 6 / \mathrm{d}$ in vessel no. 2 , but the results are not reported here in detail. In general the production of acetate and propionate increased ( 19 and $40 \%$ ) and the productions of butyrate and methane decreased ( 7 and I $4 \%$ respectively) when the dilution rate was doubled. This showed that the unusual 
Table 6. Distribution of micro-organisms in the solid and liquid phases during incubation of hay and barley by the Rumen Simulation Technique (Rusitec) as a mixture in the same bag $(A)$ or in separate bags $(B)$

\begin{tabular}{|c|c|c|c|c|c|c|}
\hline & \multicolumn{2}{|c|}{ Vol. of liquid (ml) } & \multicolumn{2}{|c|}{$\begin{array}{l}\text { Bacterial concentration } \\
\quad\left(\mathrm{no} . / \mathrm{ml}\left(\times 10^{10}\right)\right)\end{array}$} & \multicolumn{2}{|c|}{$\begin{array}{l}\text { Protozoal concentration } \\
\quad\left(\mathrm{no} . / \mathrm{ml}\left(\times 10^{4}\right)\right)\end{array}$} \\
\hline & A & $\mathbf{B}$ & $\mathbf{A}$ & B & $\mathbf{A}$ & $\mathbf{B}$ \\
\hline Effluent & 988 & 978 & $3 \cdot 0$ & $4 \cdot 0$ & $5 \cdot 8$ & 6.4 \\
\hline Washings & & & & & & \\
\hline $\left.\begin{array}{l}\text { Hay } \\
\text { Barley }\end{array}\right\}$ & 80 & $\begin{array}{l}60 \\
20\end{array}$ & $5 \cdot 3$ & $\begin{array}{l}6 \cdot 3 \\
9 \cdot 8\end{array}$ & 45.0 & $\begin{array}{l}47 \cdot 5 \\
56 \cdot 0\end{array}$ \\
\hline Residues * & & & & & & \\
\hline $\left.\begin{array}{l}\text { Hay } \\
\text { Barley }\end{array}\right\}$ & 34 & $\begin{array}{l}22 \\
10\end{array}$ & $40 \cdot 4$ & $\begin{array}{l}57 \cdot 6 \\
42 \cdot 8\end{array}$ & 190 & $\begin{array}{l}210 \\
175\end{array}$ \\
\hline
\end{tabular}

- The microbial concentration in the wet residue was calculated by assuming that the total microbial numbers in the residue were in the same proportion to the microbial markers (diaminopimelic acid and aminoethylphosphonic acid) as in the effluent. The undigested washed residue contained approximately $800 \mathrm{~g}$ water $/ \mathrm{kg}$.

Table 7. Efficiency of microbial growth and recoveries of hydrogen in the supplementation experiments*

\begin{tabular}{|c|c|c|c|c|}
\hline & \multicolumn{2}{|c|}{ Efficiency } & \multicolumn{2}{|c|}{$\begin{array}{c}\text { Hydrogen balance } \\
(\mathrm{mmol} / \mathrm{d})\end{array}$} \\
\hline & $\begin{array}{c}\text { Microbial } \\
\text { DM/VFA } \\
\text { (g/mmol) }\end{array}$ & $\begin{array}{c}\mathrm{Y}_{\mathrm{ATP}}^{\dagger} \\
(\mathrm{g} / \mathrm{mol})\end{array}$ & Produced & Recovered \\
\hline \multicolumn{5}{|l|}{ Expt I } \\
\hline Control & $26 \cdot 7$ & II $\cdot 0$ & $45 \cdot 5$ & $39 \cdot 6$ \\
\hline Glucose & 23.8 & 9.5 & $70 \cdot 7$ & $71 \cdot 7$ \\
\hline $\mathrm{NH}_{4} \mathrm{Cl}$ & 27.5 & II. 5 & $47 \cdot 6$ & $39 \cdot 3$ \\
\hline Glucose $+\mathrm{NH}_{6} \mathrm{Cl}$ & $27 \cdot 0$ & 10.9 & $86 \cdot 0$ & 84.8 \\
\hline \multicolumn{5}{|l|}{ Expt $2 a$} \\
\hline Control & $15 \cdot 5$ & $6 \cdot 2$ & $\mathbf{I} \mathbf{3} \mathbf{I} \cdot \mathbf{2}$ & $124 \cdot 0$ \\
\hline Whey & $20 \cdot 9$ & 8.5 & $166 \cdot I$ & $175 \cdot 9$ \\
\hline \multicolumn{5}{|l|}{ Expt $2 b$} \\
\hline Control & 18.9 & $7 \cdot 6$ & 199.8 & 171.8 \\
\hline Whey & $22 \cdot 2$ & $8 \cdot 7$ & $205 \cdot 4$ & $211 \cdot 2$ \\
\hline Control & $20 \cdot 2$ & $8 \cdot I$ & $18 \mathrm{r} \cdot 5$ & $171 \cdot 8$ \\
\hline \multicolumn{5}{|l|}{ Expt 3} \\
\hline Same bag & $18 \cdot 0$ & 6.5 & $27 I \cdot I$ & $270 \cdot 9$ \\
\hline Separate bags & $18 \cdot 7$ & $7 \cdot 6$ & $277 \cdot 2$ & 282.4 \\
\hline
\end{tabular}

* Calculations based on values given in Tables 1,3 and 4 .

$\dagger \mathrm{Y}_{\text {ATP }}=$ microbial DM/ATP, where ATP $=2 \mathrm{~A}+3 \mathrm{P}+2 \mathrm{~B}+{ }_{3} \mathrm{~V}+\mathrm{CH}_{4}($ Czerkawski, 1978).

$\ddagger$ Hydrogen produced $=2 \mathrm{~A}+\mathrm{P}+4 \mathrm{~B}+3 \mathrm{~V}+6 \mathrm{H}$. Hydrogen recovered $=2 \mathrm{P}+2 \mathrm{~B}+4 \mathrm{~V}+4 \mathrm{H}+4 \mathrm{CH}_{4}+8 \cdot \mathrm{I}$ $\times \mathrm{g}$ DM (Marty \& Demeyer, 1973). A, acetic; P, propionic; B, butyric; $V, C_{\S}$ acids; $H$, hexanoic acid.

fermentation obtained in this experiment (acetic:propionic: butyric, $45: 16: 25$ ) could be changed to the more usual one in which the production of propionate would be greater than that of butyrate by using the same rations but increasing the dilution rate. The digestibilities of DM were nearly the same at different dilution rates, but the output of bacteria in the effluent increased and in the undigested residue decreased when the dilution rate was doubled. 


\section{DISCUSSION}

One of the basic features of Rusitec is the ability to conduct long-term incubations, under controlled conditions, in the presence of solid digesta. The comparisons of the results reported here and previously (Czerkawski \& Breckenridge, 1977), with results obtained using continuous cultures of mixed rumen micro-organisms supplied with soluble substrates (e.g. Isaacson et al. I975) showed that the solid phase appears to be necessary for simulating normal rumen fermentation.

In general, provided that some of the nutrients are not limiting, supplementation of the basal rations in Rusitec results in predictable incremental increases in the formation of products.

Expt I showed that although the digestibility of hay alone was relatively low, $\mathrm{N}$ was not limiting and that hay constituted a balanced diet. On the other hand, the infusion of glucose without supplementation with additional $\mathrm{N}$, resulted in a changed fermentation pattern, lowering of the digestibility of the basal ration and indicated that there may be some fixation of atmospheric $\mathrm{N}_{2}$ but the accuracy of this method is not sufficient to draw any firm conclusions about the magnitude of $\mathrm{N}_{2}$ fixation. The value of output-input $(4 \mathrm{mg} \mathrm{N} / \mathrm{d}$ ) would correspond to about $20 \mathrm{mg} \mathrm{N} / \mathrm{d}$ in a sheep with 51 rumen. This should be compared with values of 0.4 and $\mathrm{I} \cdot 0 \mathrm{mg} \mathrm{N} / \mathrm{sheep}$ per d reported by Hobson et al. (1973) and Granhall \& Ciszuk (197I) respectively and with much higher values reported by Jones \& Thomas (I974) (values of about $30 \mathrm{mg} \mathrm{N} /$ sheep per d increasing to $800 \mathrm{mg} \mathrm{N} /$ sheep per $\mathrm{d}$ after addition of molasses and $\mathrm{N}_{2}$ fixing micro-organisms).

The glucose was fermented but the fermentation appeared to be uncoupled $(17 \mathrm{~g}$ additional microbial matter/mol additional VFA produced). When $\mathrm{N}$ was not limiting, the production of additional VFA resulted in production of an additional $26 \mathrm{~g}$ microbial $\mathrm{DM} / \mathrm{mol}$. Moreover, the microbial matter contained twice as much carbohydrate when $\mathrm{N}$ was limiting. During $\mathrm{N}$ limitation the output of isovaleric acid increased by about $2 \mathrm{mmol} / \mathrm{d}$ (Table I). The amount of crude protein digested under these conditions was $276 \mathrm{mg} / \mathrm{d}$ and this would correspond to about $23 \mathrm{mg} / \mathrm{d}$ of leucine digested and $0.18 \mathrm{mmol}$ of isovaleric acid produced. This is considerably smaller than the actual increase in isovaleric acid production and it is unlikely that the lower efficiency of microbial growth is due to fermentation of proteins.

Supplementation of basal rations with whey powder resulted in an increased output of end-products of fermentation and this was confined to methane, $\mathrm{CO}_{2}$, acetic and butyric acids. Clearly, lactose, the main constituent of whey powder, does not favour the production of propionic and $C_{b}$ acids (see Van Nevel et al. 1972). When hexoses are converted to acetate and butyrate there is concomitant production of $\mathrm{CO}_{2}$ and $\mathrm{H}_{2}$; thus the production of unusually large amounts of methane is not unexpected. Whey powder did not give any marked increase in the output of bacterial DM in the effluent, but there was an increase in the bacterial content of the solid undigested material. Thus, we have a situation where the soluble substrate given as a single meal seems to influence the microbial matter in the solid phase of the reaction mixture. On the other hand, when the basal ration of hay was supplemented with an infusion of glucose and $\mathrm{NH}_{4} \mathrm{Cl}$ the increase in microbial matter was mainly confined to the effluent (Table I).

The concepts of efficiency of microbial growth and stoichiometry of fermentation in the rumen are now generally accepted (e.g. see Demeyer \& Van Nevel, I974; Czerkawski, 1978). The efficiencies of microbial growth and hydrogen balances in the experiments reported here are calculated and summarized in Table 7 . The efficiency is expressed simply as the ratio of microbial matter synthesized to total VFA produced $(\mathrm{g} / \mathrm{mmol})$ or as $Y_{A T P}(\mathrm{~g} / \mathrm{mol})$. The efficiency was lower when $\mathrm{N}$ was limiting and increased when the basal diet was 
supplemented with whey. The efficiency appeared to be greater with roughage than with concentrated diet. The values compare favourably with the values reported by various workers and summarized recently (Czerkawski, 1978). The recovery of hydrogen appeared to be generally better with carbohydrate supplements (102\%, range $99-106 \%$ ) than in the unsupplemented controls ( $90 \%$, range $83-95 \%$ ).

It is impossible to measure the digestion of a specific dietary component in vivo, in the presence of other components, except in terms of increments and often the increments are not additive. By incubating two completely dissimilar dietary components (hay and barley) as mixtures or in separate bags in Rusitec, it was possible to compare quantitatively the outputs of products and to see what happened to the separate components. The results showed that there were no marked differences in the output of products, whether the dietary components were fed as mixtures or in separate bags. Therefore, it must be concluded that, although the solid phase is important, its location within the reaction vessel is not important. This offers an attractive possibility of constructing a variant of Rusitec, where the solid food would be kept stationary and it would be perfused by circulating rumen fluid.

As to be expected, the digestibilities of DM and other dietary constituents in hay and barley were quite different and since the digestibility of barley was much greater than that of hay, the amount of undigested residue from barley was correspondingly smaller and it contributed to a smaller extent to the solid phase in the reaction vessels. It was possible to show that the concentrations of both bacteria and protozoa in the liquid close to the solid phase was considerably greater than in the free liquid phase. The proportions of total protozoa and bacteria in the reaction vessel removed every day were similar to the dilution rate (approximately $0 \cdot 7 / \mathrm{d}$ ), but the proportions removed with liquid and with the undigested residues were different (approximately half the total bacteria and one-third the total protozoa were removed in the effluent). Thus it was possible to show sequestration of both bacteria and protozoa in the solid phase of the reaction mixture and that the extent of sequestration was greater with protozoa than with bacteria. The generation time of protozoa is much greater than the mean generation time of bacteria and therefore the protozoa are more likely to be washed out if the dilution rate is too great. The provision of a solid phase in the reaction vessel and the sequestration of protozoa by the solid would be expected to reduce the extent of washing out and help to maintain a normal protozoal population. This conclusion was supported by results of changing the dilution rate. The small changes in fermentation pattern with increased dilution rate were probably due to changes in bacterial distribution.

\section{REFERENCES}

Cottyn, R. G. \& Boucque, C. F. (1968). J. agric. Fd Chem. r6, 105.

Crampton, E. W. \& Maynard, L. A. (1938). J. Nutr. 15, 383.

Czerkawski, J. W. (1974). J. Sci. Fd Agric. 25, 45.

Czerkawski, J. W. (1976a). Br. J. Nutr. 36, 3I I.

Czerkawski, J. W. (1976b). J. Sci. Fd Agric. 27, 323.

Czerkawski, J. W. (1978). J. Dairy Sci. 6r, 1261

Czerkawski, J. W. \& Breckenridge, G. (1977). Br. J. Nutr. 38, 371.

Czerkawski, J. W. \& Breckenridge, G. (1978a). Proc. Nutr. Soc. 37, 53A.

Czerkawski, J. W. \& Breckenridge, G. (1978b). Proc. Nutr. Soc. 37, 54A.

Czerkawski, J. W., Christie, W. W, Breckenridge, G. \& Hunter, M. L. (1975). Br. J. Nutr. 34, 25.

Czerkawski, J. W. \& Clapperton, J. L. (I968). Lab. Pract. 17, 994.

Demeyer, D. I. \& Van Nevel, C. J. (1974). In Digestion and Metabolism in the Ruminant. [M. W. McDonald and A. C. I. Warner, editors]. Armidale: University of New England Press.

Granhall, U. \& Ciszuk, P. (1971). J. gen. Microbiol. 65, 91.

Hobson, P. N., Summers, R., Postgate, J. R. \& Ware, D. A. (1973). J. gen. Microbiol. 77, 225.

Isaacson, H. R., Hinds, F. C., Bryani, M. P. \& Owens, F. N. (1975). J. Dairy Sci. 58, I645. 
Jones, K. \& Thomas, J. G. (1974). J. gen. Microbiol. 85, 97.

Marty, R. J. \& Demeyer, D. I. (1973). Br. J. Nutr. 30, 369.

Pryce, T. D. (1969). Analyst, Lond. 94, $115 \mathrm{I}$.

Spies, J. R. (1952). J. biol. Chem. 195, 65.

Van Nevel, C. J., Demeyer, D. I. \& Henderickx, J. (1972). Proceedings of 2nd Zul. Congress on Animal Feeding, Madrid, p. 27.

Van Soest, P. J. (1963). J. Ass. off. analyt. Chem. 46, 829.

Van Soest, P. J. \& Wine, R. M. (1967). J. Ass. off. analyt. Chem. 50, 50. 